\title{
Performance of lactating crossbred cows on pasture supplemented with conventional urea or slow release urea
}

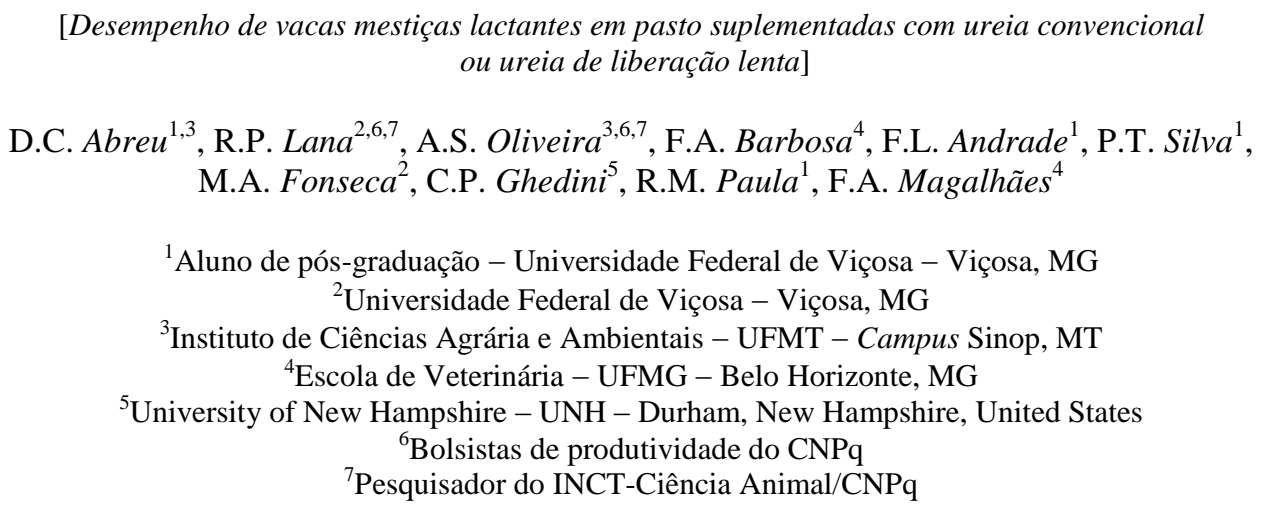

\begin{abstract}
The effect of using conventional urea (CU) or slow release urea (SRU) was evaluated by replacing soybean meal (SBM) in concentrated supplements in levels of 2, 4 or $6 \%$ (dry matter basis) on productive performance of crossbred Holstein x Zebu lactating dairy cows $(499 \pm 61 \mathrm{~kg}$ body weight and 167 days of lactation) grazing on elephant grass $(11.5 \% \mathrm{CP}$ and $60 \% \mathrm{NDF})$ under rotational grazing during the rainy season. A supplement control (no urea) was used containing SBM as a protein source. A total of 21 cows were distributed an incomplete randomized block design with three periods of 21 days each (14 days of adaptation and seven days of collection). The animals entered the paddocks with a pasture height of 110$120 \mathrm{~cm}$ and left when the grass reached the height of $40-50 \mathrm{~cm}$. The concentrated isonitrogenous supplements $(24 \%$ crude protein, dry matter basis) were provided in the amount of $3.2 \mathrm{~kg} / \mathrm{cow} / \mathrm{day}$ (fed basis). There was no effect ( $\mathrm{P}>0.05)$ on source of crude protein (SBM $v s$ source NPN), source NPN, level of NPN, interaction between source NPN and level of NPN on milk production $(10.0 \mathrm{~kg} / \mathrm{day})$, fat milk production corrected to $3.5 \%(10.7 \mathrm{~kg} /$ day), levels of fat $(4.01 \%)$, protein $(3.66 \%)$, lactose $(4.16 \%)$, total solids $(12.86 \%)$ and non-fat solids $(8.60 \%)$ in milk. The replacement of CU by SRU does not promote improvement in the productive performance of crossbred dairy cows grazing on elephant grass during the rainy season. Urea (CU or SRU) can be included in up to $6 \%$ of the DM concentrated supplements, replacing SBM, without affecting the productive performance of crossbred cows (Holstein $\mathrm{x}$ Zebu) in pasture during the rainy season.
\end{abstract}

Keywords: non-protein nitrogen, milk

\section{RESUMO}

Avaliou-se o efeito da utilização de ureia convencional (UC) ou de ureia de liberação lenta (ULL) em suplementos concentrados, nos níveis de 2, 4 ou 6\% (base da matéria seca), em substituição ao farelo de soja, sobre o desempenho produtivo de vacas mestiças Holandês x Zebu $(499 \pm 61 \mathrm{~kg}$ de peso corporal e 167 dias de lactação) mantidas em pastos de capim-elefante (11,5\% de proteína bruta e $60 \%$ de FDNcp), sob lotação intermitente, no período das chuvas. Um suplemento controle (sem ureia) foi utilizado contendo farelo de soja como fonte proteica. Foram utilizadas 21 vacas, distribuídas em delineamento em blocos incompletos balanceados, com três períodos de 21 dias cada (14 dias de adaptação e sete dias de coleta). Os animais entraram nos piquetes com altura do pasto de $110-120 \mathrm{~cm}$ e saíram quando atingiram altura de $40-50 \mathrm{~cm}$. Os suplementos concentrados isonitrogenados $(24 \%$ de proteína bruta,

Recebido em 28 de março de 2013

Aceito em 11 de março de 2014

E-mail: daniel.abreu@ufv.br

Apoio: FAPEMIG 
base da matéria seca) foram fornecidos na quantidade de $3,2 \mathrm{~kg} /$ vaca/dia (base da matéria natural). Não houve efeito $(P>0,05)$ de fonte de proteína bruta (farelo de soja vs. fonte de NNP), de interação entre fonte de NNP (UC vs. ULL) e nível de NNP (2, 4 e 6\% na MS do suplemento), de fonte de NNP e de nível de NNP e sobre a produção de leite (10,0kg/dia), produção de leite corrigida para 3,5\% de gordura $(10,7 \mathrm{~kg} /$ dia $)$, teores de gordura (4,01\%), proteina (3,66\%), lactose (4,16\%), extrato seco total $(12,86 \%)$ e extrato seco desengordurado (8,60\%) no leite. A substituição da ureia convencional pela ULL não promove melhoria no desempenho produtivo de vacas leiteiras mestiças em pastagem de capim-elefante, no período das chuvas. A ureia (convencional ou de liberação lenta) pode ser incluída em até $6 \%$ na MS de suplementos concentrados, em substituição ao farelo de soja, sem afetar o desempenho produtivo de vacas mestiças (Holandês $x$ Zebu) em pastagem, no período das chuvas.

Palavras-chave: leite, nitrogênio não proteico

\section{INTRODUCTION}

The provision of food concentrates aims to meet the nutritional needs of animals complementing the nutrients present in the forage. Therefore, it is of fundamental importance to know the nutritional characteristics of foods in order to formulate diets that meet the needs of the animals. Among nutrients, protein is considered a high cost in the diet of ruminants, which makes the economic feasibility of animal production highly dependent on the efficiency of utilization of this nutrient.

The conventional protein sources such as oilseed and their respective meals have increasing costs because of competition with grain-based human food systems. Thus, there is growing interest in the use of non-protein nitrogen (NPN) sources in supplementary feeding in ruminant nutrition. The NPN represents an alternative to completing requirements for protein and reduces the cost of this nutrient in animal nutrition (Teixeira and Salvador, 2004). A lot of studies which involve different sources and levels of protein are being published; however, much information about how to increase the use of protein supplements remains unknown. As a result, the protein supplement for dairy cattle is one of the most studied components in ruminant nutrition.

The NPN is used in ruminant nutrition replacing conventional sources of true protein. Among the sources of NPN, urea is the most widespread, mainly because of its low cost. Also, urea is widely used in partial replacement of real protein sources, mainly soybean meal (SBM). However, its high rate of hydrolysis can become a problem for the rapid release of ammonia $\left(\mathrm{NH}_{3}\right)$ and consequent accumulation of nitrogen in the rumen as ammonia, which must be absorbed and carried to the liver for metabolism and conversion into urea. In that form, the urea can be excreted by urine or recycled in rumen membrane or saliva. However, these processes waste energy and reduce the availability of energy in the rumen.

The amount of $\mathrm{N}$ required by microorganisms is a function of the amount of energy available in the rumen, because bacteria and protozoa ciliates need sources of nitrogen and energy simultaneously for desirable proliferation to occur (Lucci, 1997). For this reason, urea is best used as a source of nitrogen for protein synthesis, when there is synchronization between the release of energy and nitrogen (Akay et al., 2004). It is possible to control the rate of hydrolysis when it occurs at a speed synchronized with the availability of energy. This enables the conversion of ammonia nitrogen in ruminal microflora, leading to the reduction of output and accumulation of ammonia in the rumen.

With the implementation of new technologies over the last 30 years, products have been developed that seek to control the release of NPN in order to improve the conversion of $\mathrm{N}$ into microbial protein and reduce the cost of concentrate in the diets. Recently, a treatment was developed for encapsulating urea with biodegradable polymers capable of slowly releasing the ammonia nitrogen $\left(\right.$ Optigen $\left.{ }^{\circledR}\right)$. However, studies of slow release urea (SRU) in diets of dairy cows are quite scarce. Most of the published data are related to ruminal parameters and not to animal performance and are geared primarily towards the nutrition of beef cattle (Loest et al., 2001; Akay et al., 2004). 
This study aimed to evaluate the effects of the inclusion $(2,4$, or $6 \%$ as fed basis) of conventional urea and slow release urea replacing soybean meal, compared to control treatment on intake, digestibility, milk production and milk composition of dairy cows grazing on elephant grass.

\section{MATERIAL AND METHODS}

This study was conducted in the experimental unit of the Dairy Research Center at the Animal Science Department, Viçosa, in the state of Minas Gerais, Brazil belonging to the Universidade Federal de Viçosa in the area managed with rotational grazing elephant grass (Pennisetum purpureum) in the rainy season, from March to May 2010.

Viçosa is located in the Zona da Mata, between the hills of Mantiqueira, Caparaó and Piedade. It lies at an altitude of 649 meters and has the geographical coordinates of the parallel $20^{\circ} 45^{\prime} 14^{\prime \prime} \mathrm{S}$ latitude and the meridian of $42^{\circ} 52^{\prime} 54^{\prime \prime}$ W longitude Gr. The climate is Cwa (mesothermal), according to the Köppen classification, with two well-defined seasons, with hot, humid summers and cold, dry winters. The average rainfall is $1,341.2 \mathrm{~mm}$ per year. The maximum and minimum temperatures are $26.1^{\circ}$ and $14.0^{\circ} \mathrm{C}$, respectively (Universidade..., 1997). The pastures are divided into six paddocks fertilized with waste from pig farms and provided with troughs and salt. The area has a lack of shade and slightly undulating topography. During the experiment the paddocks were managed seeking to maintain high average pregrazing sward height of $110-120 \mathrm{~cm}$ and postgrazing residual height of $40-50 \mathrm{~cm}$ (Oliveira, 2006) in order to ensure adequate residue for regrowth after grazing in the rest period following.

A total of 21 multiparous crossbred Holstein $\mathrm{x}$ Zebu cows, with potential milk production of $3,000-4,500 \mathrm{~kg}$ per lactation and an initial average body weight (BW) of $499 \pm 61 \mathrm{~kg}$ were used. Seven concentrated isonitrogenous supplements were provided $(24 \%$ crude protein fed basis) in the amount of $3.2 \mathrm{~kg} / \mathrm{cow} /$ day (fed basis): SBM (control); 2, 4 or $6 \%$ urea in the concentrate (as fed basis); and 2, 4 or $6 \%$ of SRU in the concentrate (Tab. 1). The sulfur source (ammonium sulphate) was added to the urea and SRU in the ratio of $9: 1$. The concentrated supplements have been formulated to meet the requirements of crude protein $(\mathrm{CP})$ and total digestible nutrients and trace minerals, according to the NRC (National..., 2001).

Table 1. Ingredient composition of the experimental concentrated supplements (dry matter)

\begin{tabular}{lccccccc} 
& & \multicolumn{5}{c}{ Source of non-protein nitrogen } \\
\cline { 3 - 7 } Components & Soybean & \multicolumn{3}{c}{ Urea (\% of DM) } & \multicolumn{3}{c}{ SRU (\% of DM) } \\
\cline { 3 - 8 } & meal & 2 & 4 & 6 & 2 & 4 & 6 \\
\hline Corn meal & 58.5 & 69.0 & 79.5 & 90.0 & 69.0 & 79.5 & 90.0 \\
Soybean meal & 37.5 & 25.0 & 12.5 & - & 25.0 & 12.5 & - \\
Urea conventional & - & 2.0 & 4.0 & 6.0 & - & - & - \\
Slow release urea & - & - & - & - & 2.0 & 4.0 & 6.0 \\
Mineral mix & 4.0 & 4.0 & 4.0 & 4.0 & 4.0 & 4.0 & 4.0 \\
\hline
\end{tabular}

The experiment was analyzed in an incomplete randomized block design (Cochran and Cox, 1968), as shown in Tab. 2.

The animals were managed under grazing condition, in the period between milking, and were given supplements twice a day for milking in the morning and afternoon, with free access to a salt trough that contained mineral mixture, and the water trough. The animals were weighed at the beginning and end of each trial period.
Table 2. Delineation on a balanced incomplete block design with seven treatments, using seven cows and three periods

\begin{tabular}{cccc}
\hline \multirow{2}{*}{ Cow } & \multicolumn{3}{c}{ Period } \\
\cline { 2 - 4 } & I & II & III \\
\hline 1 & 7 & 1 & 4 \\
2 & 1 & 2 & 5 \\
3 & 2 & 3 & 6 \\
4 & 3 & 4 & 7 \\
5 & 4 & 5 & 1 \\
6 & 5 & 6 & 2 \\
7 & 6 & 7 & 3 \\
\hline
\end{tabular}


Sampling of pasture (with a quadrant-based sampling of $1 \times 1$ meters in 10 areas/paddock, with forage clipped close to the ground in the spot that has equivalent height to the average pasture height, and simulated grazing) was made prior to the entry and exit of animals in each paddock and sampling of concentrate. Samples of pasture and feed concentrates were dried in an oven with forced ventilation $\left(60^{\circ} \mathrm{C}\right.$ for 72 hours) and, together with the feedstuffs, were processed in a grinder with a sieve's porosity at $1 \mathrm{~mm}$ for chemical analysis.

The analysis of DM, CP (total nitrogen x 6.25), acid detergent fiber (ADF), lignin (HSO 72\% w/w) were performed according to methods described in Silva and Queiroz (2002). For analyzing the concentration of neutral detergent fiber (NDF), the samples were treated with thermostable alpha amylase without the use of sodium sulfite, corrected for ash residue (Mertens, 2002) and residual nitrogen compounds (Licitra et al., 1996). Analyses of $\mathrm{NDF}$ and ADF were performed in the Ankon ${ }^{\circledR}$ system using TNT bags (non-woven-fabric), with dimensions of $5 \mathrm{~cm} \times 5 \mathrm{~cm}$, maintaining relationships average of $14 \mathrm{mg} \mathrm{DM} / \mathrm{cm}$ tissue and $100 \mathrm{~mL}$ of detergent/g of dry sample in air.

The total carbohydrates were calculated according to Sniffen et al. (1992), wherein: CT = $100-(\%$ of $\mathrm{CP}+\%$ of $\mathrm{EE}+\%$ of ash). The NFC were calculated as proposed by Hall (200): NFC $=100-[(\%$ of CP $-\%$ CP of urea $+\%$ of Urea + $\%$ of $\mathrm{NDF}_{\text {ap }}+\%$ of $\mathrm{EE}+\%$ of ash)].

The concentration of indigestible acid detergent fiber (iADF) in food was obtained after incubation of ruminal foods, leftovers and feces in polyester bags $\left(\right.$ Ankon ${ }^{\circledR}$, filter bag 57) for a period of 264 hours, according Casali et al. (2008).

The chemical composition of elephant grass, corn meal and SBM are presented in Tab. 3, while the chemical compositions of concentrated supplements are in Tab. 4. The samples of elephant grass were dried at $65^{\circ} \mathrm{C}$, grinder equipped with $1 \mathrm{~mm}$ diameter sieves and stored along with SBM and corn meal.

Cows were milked mechanically twice daily, at 6:00 and 14:00 hours, making up the daily record of milk production during the last seven days of each experimental period.

Milk was sampled from each animal (first and second milking) during the last two days of each period. The samples were placed in plastic bottles with Bronopol $^{\circledR}$ for subsequent determination of milk components, such as protein, fat, lactose and total solids at the Laboratory of Milk Quality in Centro Nacional de Pesquisa de Gado de Leite, CNPGL/EMBRAPA, in Juiz de Fora, Minas Gerais state, Brazil, using methods described by IDF (1996). The averages of the milk samples analyzed were considered in order to calculate the corrected milk 3.5\% fat (PLcor), which was done using the following formula derived from Tyrrell and Reid (1965), cited by Leiva et al. (2000): PLcor $=12,82 * \mathrm{P}_{\text {fat }}+7,13 * \mathrm{P}_{\mathrm{ptn}}+0,323$ * MP, in which: MP = Milk production, $\mathrm{kg} / \mathrm{day}$; $\mathrm{P}_{\text {fat }}=$ fat production, $\mathrm{kg} /$ day; $\mathrm{e} \mathrm{P}_{\mathrm{ptn}}=$ protein production, $\mathrm{kg} / \mathrm{day}$.

Table 3. Chemical composition of elephant grass, corn and soybean meal

\begin{tabular}{lccc}
\hline Item & $\begin{array}{c}\text { Elephant } \\
\text { grass }\end{array}$ & $\begin{array}{c}\text { Corn } \\
\text { meal }\end{array}$ & $\begin{array}{c}\text { Soybean } \\
\text { meal }\end{array}$ \\
\hline Dry matter (\%) & 15.49 & 88.26 & 88.81 \\
Crude protein (\% of DM) & 11.47 & 8.85 & 49.28 \\
Ash (\% of DM) & 12.16 & 1.72 & 6.19 \\
Neutral detergent insoluble protein (\% of DM) & 5.70 & 3.56 & 2.04 \\
Acid detergent insoluble protein (\% of DM) & 2.90 & 1.24 & 0.95 \\
Ether extract (\% of DM) & 1.82 & 4.13 & 1.30 \\
Total carbohydrates (\% of DM) & 74.55 & 85.30 & 43.23 \\
Neutral detergent fiber (NDF) (\% of DM) & 64.29 & 12.82 & 11.27 \\
NDF corrected for ash and protein (\% of DM) & 60.19 & 11.62 & 6.81 \\
Non-fibrous carbohydrates (\% of DM) & 10.26 & 72.48 & 31.96 \\
Acid detergent fiber (ADF) (\% of DM) & 38.95 & 1.92 & 8.81 \\
Indigestible acid detergent fiber (iADF) (\% of DM) & 12.48 & 0.65 & 0.02 \\
\hline
\end{tabular}


Performance of lactating...

Table 4. Chemical composition of the experimental concentrate supplements

\begin{tabular}{|c|c|c|c|c|c|c|c|}
\hline \multirow{2}{*}{ Item } & \multirow{2}{*}{$\begin{array}{l}\text { Soybean } \\
\text { meal }\end{array}$} & \multicolumn{3}{|c|}{ Urea $(\%)$} & \multicolumn{3}{|c|}{ SRU (\%) } \\
\hline & & 2 & 4 & 6 & 2 & 4 & 6 \\
\hline Dry matter $(\%)$ & 88.88 & 89.02 & 89.17 & 89.31 & 89.02 & 89.17 & 89.31 \\
\hline Ash (\% of DM) & 7.33 & 6.73 & 6.14 & 5.55 & 6.73 & 6.14 & 5.55 \\
\hline Crude protein (\% of DM) & 23.66 & 23.67 & 23.68 & 23.69 & 23.80 & 23.95 & 24.09 \\
\hline $\begin{array}{l}\text { Neutral detergent fiber ( } \% \text { of } \\
\text { DM) }\end{array}$ & 11.73 & 11.66 & 11.60 & 11.54 & 11.66 & 11.60 & 11.54 \\
\hline Acid detergent fiber ( $\%$ of $\mathrm{DM})$ & 4.43 & 3.53 & 2.63 & 1.73 & 3.53 & 2.63 & 1.73 \\
\hline $\begin{array}{l}\text { Indigestible acid detergent fiber } \\
\text { (\% of DM) }\end{array}$ & 0.39 & 0.45 & 0.52 & 0.59 & 0.45 & 0.52 & 0.59 \\
\hline Ether extract $(\%$ of DM) & 2.90 & 3.17 & 3.45 & 3.72 & 3.17 & 3.45 & 3.72 \\
\hline $\begin{array}{l}\text { Acid detergent insoluble protein } \\
(\% \text { of } \mathrm{DM})\end{array}$ & 1.08 & 1.09 & 1.10 & 1.12 & 1.09 & 1.10 & 1.12 \\
\hline $\begin{array}{l}\text { Neutral detergent insoluble } \\
\text { protein }(\% \text { of } \mathrm{DM})\end{array}$ & 2.85 & 2.97 & 3.09 & 3.20 & 2.97 & 3.09 & 3.20 \\
\hline $\begin{array}{l}\text { Neutral detergent fiber corrected } \\
\text { for ash and protein }(\% \text { of } D M)\end{array}$ & 9.35 & 9.72 & 10.09 & 10.46 & 9.72 & 10.09 & 10.46 \\
\hline $\begin{array}{l}\text { Non-fibrous carbohydrates ( } \% \text { of } \\
\text { DM) }\end{array}$ & 54.38 & 54.77 & 55.13 & 55.50 & 54.64 & 54.86 & 55.10 \\
\hline
\end{tabular}

Data were subjected to analysis of variance and regression, using the PROC GLM feature of the SAS statistical package, version 9.0 for Windows, adopting a 5\% level of probability for error type I. The variables were analyzed in randomized incomplete block design with treatments arranged so that, in each period, there was a complete block, according to the statistical model:

$$
\mathrm{Y}_{\mathrm{ijk}}=\mu+\mathrm{B}_{\mathrm{i}}+\mathrm{T}_{\mathrm{j}}+\mathrm{Te}_{\mathrm{ijk}}
$$

$\mathrm{Y}_{\mathrm{ijk}}=\mathrm{i}$ animal, $\mathrm{j}$ undergoing treatment in the period k;

$\mu=$ overall effect of the mean;

$\mathrm{B}_{\mathrm{i}}=$ end of block (cow) $\mathrm{i}$, where $\mathrm{i}=1,2,3,4,5$, 6,7 ;

$\mathrm{T}_{\mathrm{j}}=$ treatment effect $\mathrm{j}$, and $\mathrm{j}=1,2,3,4,5,6,7$;

$\mathrm{T}_{\mathrm{k}}=$ effect of length $\mathrm{k}$, where $\mathrm{k}=1,2,3$;

$\mathrm{e}_{\mathrm{ijk}}=$ random error associated with each observation ijk.

Five contrasts were applied: SBM $v s$ NPN, effect of NPN source (urea $v s$. SRU); effect of level of NPN (linear and quadratic), and interaction effect between source of NPN and level of NPN. The means were presented as means of least squares.

\section{RESULTS AND DISCUSSION}

There was no effect $(\mathrm{P}>0.05)$ in the replacement of SBM with NPN on BW, milk yield and milk composition (Tab. 5). Other authors have observed no effect in the substitution of an organic protein source by urea on milk yield and milk composition. Rangel et al. (2005), working with dairy cows fed isonitrogenous diets based on sugar cane and soybean meal containing 0.4 , 0.8 or $1.2 \%$ mixture of urea and ammonium sulphate (9:1) in sugar cane, there was also no difference observed in milk yield (average 20 $\mathrm{kg} /$ day) and milk composition.

Imaizumi et al. (2003), using cows producing around $12 \mathrm{~kg}$ milk/day, fed corn silage instead, found that the partial replacement of soybean meal by urea $(1.3 \%$ DM) did not affect the milk production.

Santos et al. (1998) summarized 23 comparisons in which conventional urea replaced partially or totally by true protein sources for housed cows with yields ranging from 29 to $42 \mathrm{~kg}$ milk/day. Milk production was not affected in 20 out of 23 comparisons and decreased in only three, with the inclusion of urea in the rations.

Souza et al. (2010) evaluating the effects of the partial replacement of SBM by SRU in lactating Holstein cows producing $42 \mathrm{~kg}$ of milk/day in a free-stall barn, found that the partial replacement did not decrease the milk yield or milk composition. 
Table 5. Production and composition of milk as a function of concentrates in the diet of crossbred Holstein $x$ Zebu cows

\begin{tabular}{|c|c|c|c|c|c|c|c|c|c|c|c|c|}
\hline \multirow{3}{*}{ Item } & \multirow{3}{*}{ SBM } & \multicolumn{6}{|c|}{ Souce of Nonprotein nitrogen (NPN) } & \multirow{3}{*}{$\begin{array}{l}\mathrm{CV} \\
(\%)\end{array}$} & \multicolumn{4}{|c|}{ Contrasts (Valor- $P$ ) } \\
\hline & & \multicolumn{3}{|c|}{ Urea (\%) } & \multicolumn{3}{|c|}{ SRU (\%) } & & \multirow{2}{*}{$\begin{array}{c}\text { SBM } \\
v s . \\
\text { NPN }\end{array}$} & \multirow{2}{*}{$\begin{array}{c}\mathrm{U} \\
v s \\
\text { SRU } \\
\end{array}$} & \multicolumn{2}{|c|}{$\begin{array}{l}\text { Level of } \\
\text { NPN }\end{array}$} \\
\hline & & 2 & 4 & 6 & 2 & 4 & 6 & & & & $\mathrm{~L}$ & $\mathrm{Q}$ \\
\hline $\begin{array}{l}\text { Milk yield } \\
\text { (kg/day) }\end{array}$ & 10.37 & 10.12 & 9.30 & 9.40 & 10.28 & 10.18 & 10.32 & 31.70 & 0.77 & 0.54 & 0.81 & 0.79 \\
\hline $\begin{array}{l}\text { Corrected } \\
\text { milk } \\
\text { (kg/day) }\end{array}$ & 10.61 & 10.70 & 9.80 & 10.12 & 11.42 & 11.00 & 11.20 & 30.48 & 0.95 & 0.37 & 0.78 & 0.68 \\
\hline Fat $(\%)$ & 3.69 & 3.88 & 3.90 & 4.09 & 4.24 & 4.07 & 4.20 & 20.64 & 0.32 & 0.44 & 0.81 & 0.66 \\
\hline $\begin{array}{l}\text { Protein } \\
(\%)\end{array}$ & 3.64 & 3.60 & 3.64 & 3.65 & 3.62 & 3.80 & 3.66 & 14.07 & 0.91 & 0.71 & 0.85 & 0.61 \\
\hline $\begin{array}{l}\text { Lactose } \\
(\%)\end{array}$ & 4.34 & 4.08 & 4.05 & 4.12 & 4.31 & 4.14 & 4.05 & 13.30 & 0.40 & 0.67 & 0.65 & 0.82 \\
\hline
\end{tabular}

$\mathrm{CV}=$ coefficient of variation; SBM vs. NPN = soybean meal versus nonprotein nitrogen; U vs SRU = urea versus slow release urea; $\mathrm{L}=$ linear effect of level of $\mathrm{NPN} ; \mathrm{Q}=$ quadratic effect of $\mathrm{NPN}$; $\mathrm{BW}=$ body weight.

The efficiency of utilization of true protein and NPN sources may be interfered by a high concentration of ammonia in the rumen, observed usually three to five hours after the feeding of bran protein, one to two hours after administration of urea and 16 hours after providing SRU (Guimarães Júnior et al., 2007). Optimizing the use of ammonia depends on balancing the diet, mainly by the addition of concentrated energy that creates appropriate conditions for the use of NPN (maximizing production of microbial protein). Apparently, the energy availability of pasture and supplement favored the use of ammonia coming from the source of dietary NPN, even at the highest levels of NPN in the supplement.

The effect of SRU with calcium chloride $(0.61 \%$ of DM) in partial replacement for soybean meal in diets of dairy cows was studied by Golombesk et al. (2006). They observed that the use of SRU improved feed efficiency due to reduction of the dry matter intake, without affecting milk production.

The same effect of the SRU polymer used in this study was evaluated by Gallo et al. (2003). The authors partially replaced true protein sources by conventional urea in rations of high producing dairy cows $(35 \mathrm{~kg}$ of milk/day) in three diets. Two diets with $18 \%$ of CP (with or without the addition of $0.77 \%$ of SRU in DM) and another one with $16 \%$ of $\mathrm{CP}$ and $0.77 \%$ of urea in $\mathrm{DM}$ basis containing SRU. Milk production was highest for the treatment containing $18 \%$ of $\mathrm{CP}$ without SRM (35.6kg of milk/day), intermediate for the treatment containing $18 \%$ of $\mathrm{CP}$ with SRU (34.8kg of milk/day) and lowest in diets containing $16 \%$ of $\mathrm{CP}$ and $0.77 \%$ of SRU (33.8kg of milk/day).

There was no effect $(\mathrm{P}>0.05)$ on the different sources of NPN (urea $v s$. SRU), level of NPN, and interaction between source of NNP and level of NNP on BW, milk yield, fat corrected milk, protein, and non fatty dry extract. Thus, due to the higher price, which is usually three times the price of urea, it is questionable to use SRU to replace conventional urea in diets for low production cows under pasture regimen.

It would be expected that the increase in milk yield with the replacement of urea with SRU for synchronizing release of ammonia with energy metabolism in the rumen would lead to better utilization of ruminal ammonia by microorganisms, optimization of the synthesis of bacterial protein and consequent reduction of the uptake by rumen papillae towards the liver (metabolism in the urea cycle). However, recycling of urea in the rumen (Hall et al., 2007; Reynolds et al., 2008) may have been a factor compensating the higher release rate of urea, 
which may explain the lack of effect on animal performance.

When the levels of conventional urea were increased, there was an increase in the balance of the feed, but the increase in the levels of SRU increased spending in the use of concentrate, thus reducing the balance of the feed. These results demonstrate the infeasibility of using SRU in the diet of crossbred cows to replace conventional urea (Tab. 6).

Table 6. Balance of food obtained on the basis of conventional urea and slow release to replace soybean meal

\begin{tabular}{|c|c|c|c|c|c|c|c|}
\hline \multirow{2}{*}{ Item } & \multirow[b]{2}{*}{ FS } & \multicolumn{3}{|c|}{ Urea $(\%)$} & \multicolumn{3}{|c|}{ SRU (\%) } \\
\hline & & 2 & 4 & 6 & 2 & 4 & 6 \\
\hline Milk yield $^{1}$ (kg/day) & 10.00 & 10.00 & 10.00 & 10.00 & 10.00 & 10.00 & 10.00 \\
\hline Milk sold per $\operatorname{cow}^{2}$ (R $\$ /$ day) & 6.80 & 6.80 & 6.80 & 6.80 & 6.80 & 6.80 & 6.80 \\
\hline Cost of concentrate $^{3}(\mathrm{R} \$ /$ day $)$ & 2.09 & 2.04 & 1.99 & 1.94 & 2.18 & 2.26 & 2.35 \\
\hline Cost of pasture ${ }^{4}(\mathrm{R} \$ /$ day) & 0.47 & 0.47 & 0.47 & 0.47 & 0.47 & 0.47 & 0.47 \\
\hline Cost of feed ( $\mathrm{R} \$ /$ day) & 2.56 & 2.51 & 2.46 & 2.41 & 2.65 & 2.73 & 2.82 \\
\hline Cost of feed (base 100) & 100 & 98.05 & 96.09 & 94.14 & 104 & 107 & 110 \\
\hline Balance of feed (R $\$ /$ day) & 4.24 & 4.29 & 4.34 & 4.39 & 4.15 & 4.07 & 3.98 \\
\hline Balance (base 100) & 100 & 101 & 102 & 104 & 97.88 & 95.99 & 93.87 \\
\hline Balance of feed ( $\mathrm{R} \$ / \mathrm{kg}$ of milk) & 0.42 & 0.43 & 0.43 & 0.44 & 0.42 & 0.41 & 0.40 \\
\hline $\begin{array}{l}\text { Relationship food expense/value of production } \\
(\%)\end{array}$ & 37.65 & 36.91 & 36.18 & 35.44 & 38.97 & 40.15 & 41.47 \\
\hline
\end{tabular}

${ }^{1}$ Since there was no treatment effect $(\mathrm{P}>0.05)$, we used the average value for all treatments.

${ }^{2}$ Milk price (R\$/kg): 0.68 - Practiced by Nestlé in Curvelo, state of Minas Gerais, Brazil, on 05/06/2010.

${ }^{3}$ Cost of concentrates $(\mathrm{R} \$ / \mathrm{kg}$ of $\mathrm{DM}): 0.65,0.64,0.62,0.61,0.68,0.71$ and 0.73 , calculated from the prices charged by Itambé (Belo Horizonte, Minas Gerais state, Brazil).

${ }^{4}$ Cost of renting the pasture (R\$/animal/day).

\section{CONCLUSIONS}

The replacement of conventional urea by slow release urea did not promote improvement in the productive performance of crossbred dairy cows in tropical pastures during the rainy season. Urea (fast or slow release) can be included in up to $6 \%$ of DM in concentrated supplements, replacing soybean meal, without affecting the productive performance of crossbred dairy cows.

\section{REFERENCES}

AKAY, V.; TIKOFSKY, J.; HOLTZ, C.; DAWSON, K. Optigen ${ }^{\circledR}$ 1200: controlled release of non-protein nitrogen in the rumen. In: NUTRITIONAL BIOTECHNOLOGY IN THE FEED AND FOOD INDUSTRIES, Alltech`s Twenty First Annual Simposium, 20., 2004, Nottingham. Proceedings... Nottingham: Nottingham University Press, 2004. p.179-185.

CASALI, A.O.; DETMANN, E.; VALADARES FILHO, S.C. et al. Influência do tempo de incubação e do tamanho de partículas sobre os teores de compostos indigestíveis em alimentos e fezes bovinas obtidos por procedimentos in situ. Rev. Bras. Zootec., v.37, p.335342, 2008.
COCHRAN, W.G.; COX, G.M. Experimental designs. 2. ed. New York: WILEY, 1968. 611p.

GALLO, E.; EMANUELE, S.M.; SNIFFEN, C.J. et al. Effects of a polymer-coated urea product on nitrogen metabolism in lactating Holstein dairy cattle. J. Dairy Sci., v.86, p.2154-2162, 2003.

GOLOMBESKI, G.L.; KALSCHEUR, K.F.; HIPPEN, A.R.; SHINGOETHE, D.J. Slow release urea and highly fermentable sugars in diets fed to lactating dairy cows. J. Dairy Sci., v.89, p.4395-4300, 2006.

GUIMARÃES JUNIOR, R.; PEREIRA, L.G.R.; TOMICH, T.R. et al. Ureia na alimentação de vacas leiteiras. Planaltina, D.F.: Embrapa Cerrados, 2007. $33 \mathrm{p}$.

HALL, M.B.; HUNTINGTON, G.B. Nutrient synchrony: Sound in theory, elusive in practice. $J$. Anim. Sci., v.86, p.287-292, 2008.

IMAIZUMI, H.; SANTOS, F.A.P.; PIRES, A.V. et al. Avaliação de diferentes fontes e teores de proteína na dieta sobre o desempenho, fermentação ruminal e parâmetros sanguíneos de vacas da raça Holandesa em final de lactação. Acta Scientiarum, v.25, p.1031-1037, 2003. 
INTERNATIONAL dairy federation-IDF. Whole milk determination of milkfat, protein and lactose content. Guide fir the operation of mid-infra-red instruments. Bruxelas: 1996. 12p. (IDF Standard 141 B).

LEIVA, E.; HALL, M.B.; VAN HORN, H.H. Performance of dairy cattle fed citrus pulp or corn products as source of neutral detergent-soluble carbohydrates. J. Dairy Sci., v.83, p.2866-2875, 2000.

LICITRA, G.; HERNANDEZ, T.M.; VAN SOEST, P.J. Standardization of procedures for nitrogen fractionation of ruminant feeds. Anim. Feed Sci. Technol., v.57, p.347-358, 1996.

LOEST, C.A.; TITGEMEYER E.C.; DROUILLARD J.S. et al. Urea and biuret as nonprotein nitrogen sources in cooked molasses blocks for steers fed prairie hay. Anim. Feed Sci. Technol., v.94, p.115-126, 2001.

LUCCI, C.S. Nutrição e manejo de bovino leiteiro. São Paulo: MANOLE, 1997. 169p.

MERTENS, D.R. Gravimetric determination of amylase-treated neutral detergent fiber in feeds with refluxing in beaker or crucibles: collaborative study. $J$. AOAC International, v.85, p.1217-1240, 2002.

NRC - NATIONAL reserch council-NRC. Nutrient requirements of dairy cattle. 7. ed. rev. Washington, D.C.: NATIONAL ACADEMY PRESS, 2001. 381p.

OLIVEIRA, P.P.A. Dimensionamento de piquetes para bovinos leiteiros, em sistemas de pastejo rotacionado. São Carlos. SP: EMBRAPA PECUÁRIA SUDESTE, 2006. 4p. (Comunicado técnico 65).
RANGEL, A.H.N.; CAMPOS, J.M.S.; OLIVEIRA, A.S. et al. Desempenho e parâmetros nutricionais de fêmeas leiteiras em crescimento alimentadas com silagem de milho ou cana-de-açúcar com concentrado. Rev. Bras. Zootec., v.39, p.2518-2526, 2010.

REYNOLDS, C.K.; KRISTENSEN, N.B. Nitrogen recycling through the gut and the nitrogen economy of ruminants: An asynchronous symbiosis. J. Anim. Sci., v.86, p.293-305, 2008.

SANTOS, F.A.P.; HUBER, J.T.; THEURER, C.B. Milk yield and composition of lactating cows fed steam-flaked sorghum and graded concentrations of ruminally degradable protein. J. Dairy Sci., v.81, p.215-220, 1998.

SILVA, D.J.; QUEIROZ, A.C. Análise de alimentos: métodos químicos e biológicos. 3.ed. Viçosa, MG: EDITORA UFV, 2002. 235p.

SNIFFEN, C.J.; O'CONNOR, J.D.; VAN SOEST, P.J. et al. A net carbohydrate and protein system for evaluating cattle diets. II. Carbohydrate and protein availability. J. Anim. Sci., v.70, p.3562-3577, 1992.

SOUZA, V.L.; ALMEIDA, R.; SILVA, D.F.F. et al. Substituição parcial de farelo de soja por ureia protegida na produção e composição do leite. Arq. Bras. Med. Vet. Zootec., v.62, p.1415-1422, 2010.

TEIXEIRA, J.C.; SALVADOR, F.M. Amireia: "Uma revolução na nutrição de ruminantes". Lavras: [s.n.] 2004. 2004. p. 174.

UNIVERSIDADE Federal De Viçosa - UFV. Dados climáticos. Viçosa, MG: Departamento de Engenharia Agrícola. Estação meteorológica, 1997. 86p. 